\title{
GENDER DIFFERENCES IN ENTREPRENEURSHIP EDUCATION OF THE STUDENTS OF MANAGEMENT
}

\author{
Martin Pech ${ }^{1}$, Petr Řehoř $\check{\check{r}}^{1}$ \\ ${ }^{1}$ Department of Management, Faculty of Economics, University of South Bohemia in České Budějovice, \\ Studentská 13, 37005 České Budějovice, Czech Republic
}

Link to this article: https://doi.org/10.11118/actaun.2021.040

Received: 16. 6. 2020, Accepted: 10. 6. 2021

To cite this article: PECH MARTIN, ŘEHOŘ PETR. 2021. Gender Differences in Entrepreneurship Education of the Students of Management. Acta Universitatis Agriculturae et Silviculturae Mendelianae Brunensis, 69(4): 455-465.

\begin{abstract}
The development of entrepreneurship competencies is not the primary objective of the management education system. Given the lack of student competencies required to start a new enterprise, the importance of entrepreneurship and economic education is increasing. There are new intentions from the Czech Republic's state politics that early business can be positively influenced and supported. The paper discusses entrepreneurship and its educational role. The research relies on a 214 questionnaire survey administered in 2018-2019 on students of the University of South Bohemia in České Budějovice. The paper focuses on the assessment of gender differences of management students in entrepreneurship education. We reduced 19 variables to three decisive factors - attitudes, knowledge, and entrepreneurship competence using factor analysis. Differences were found in the personal attitudes to entrepreneurship within gender, while the difference was not confirmed in the required entrepreneurial competencies and preferred knowledge. The study deals with a vital gender topic, and its results can be beneficial for the fields of management and education, especially for their overlap.
\end{abstract}

Keywords: entrepreneurship, education, factor analysis, students, competence, attitudes, knowledge, management

\section{INTRODUCTION}

Due to global world changes in the business environment, entrepreneurship is currently on education in schools. The importance of education for entrepreneurship is increasing in coping with the conditions in the current working and living environment (Kuttim et al., 2014). Entrepreneurship will play a decisive role in preparing for the future. It is what drives people forward and is very important for the growth of enterprises. Entrepreneurship includes an impact on the economic development and success of countries. The positive relation between the enterprises and economic growth examined Stoica, Roman and Rusu (2020). Entrepreneurship refers to the ability to use opportunities, creativity and imagination to form new ideas that are then realised in real working experience. As Matlay and
Westhead (2005) noted, entrepreneurship is turning into a daily motive, people's motto.

Many empirical studies investigate the role of gender in entrepreneurship. Based on the research of Křižzová et al. (2011), the element of gender segregation is one of the main ones that determine the position of women in employment. The Czech environment instead supports the traditional division of roles; from the point of view of social policy, the conditions are more favourable for female employees than for female entrepreneurs (Dlouhá et al., 2014). Regarding the structure of entrepreneurial women and men by fields of business, women are more interested in the fields: business, public, social and personal services, real estate and renting, health and social care (Jurik et al., 2016). A survey prepared by METRO (2020) and conducted during August and 
September 2017 shows that almost one in three women in the Czech Republic dreams of their own business. The GEM survey showed that men are about three times more likely than women to start a business after graduation. About 33\% of men and $21 \%$ of women think they have a good business opportunity (Lukeš and Jakl, 2007). Over the last five years, women' entrepreneurship has been on an upward trend. Their number increased by more than 10.000 to a total of 735.005 women entrepreneurs with 962.343 trade licenses; the increase in 2018 is 35\% higher than the increase in 2017. Women entrepreneurs are much happier with their lives and income than women in employment. This finding follows from the results of a survey and analysis of the Association of Small and Medium-Sized Enterprises and Self-Employed Persons of the Czech Republic (AMSP CR, 2014).

This paper aims to determine the main entrepreneurship education variables such as abilities, skills and traits among the students of management programs concerning gender differences. A partial objective is to identify a group of representative factors related to entrepreneurship using the factor analysis. The ambition is to answer the research question: "How affect the gender of students of management the entrepreneurship education"? Our research is motivated by the idea that women have a different approach to entrepreneurship education, i.e. as a different relationship to entrepreneurship or starting their own business. Entrepreneurial women usually prefer other fields than men entrepreneurs, especially services or social entrepreneurship. Gender is an important factor, especially concerning stereotypes about women in the labour market.

\section{Theoretical Framework}

Entrepreneurship education could be defined as a unique form of training in business knowledge. Wei, Liu and Sha (2019) notice that entrepreneurship education is necessary for entrepreneurs to gain resources, learn, improve, and develop new competencies, professional skills, and personality traits. Although many recent studies have been carried out on entrepreneurship education, practical action is needed, especially from a European perspective (Fellnhofer, 2019).

Academic courses lead to better students' intentions and begin their own business (McGee et al., 2009). Many similar studies show that completing entrepreneurship courses will increase students' intention to engage in entrepreneurial activities (Pihie and Akmaliah, 2009). For example, Burch, Murphy and Tocher (2019) found that perceived norms, personality traits, and education and business attitudes influence entrepreneurship education intentions. Entrepreneurship courses can help eliminate business concerns and gain confidence in the realisation of a business plan. Theoretically, as noted by Pulka et al. (2014), it is attainable to evaluate these approaches of students to entrepreneurship education and entrepreneurship using cognitive, emotional, and behavioural attitudes. Essentially, it is businessrelated knowledge, emotions that awaken the needs and behaviours of whether they are willing to start a business (Rudhumbu et al., 2016). By Gürol and Atsan (2005), the students, who want to do business, have specific personality traits. These include a more significant risk appetence, internal self-control, the necessity to achieve success, and innovation capabilities.

Entrepreneurial competencies in line with Inyang and Enuoh (2009) can be understood as a "bunch" of skills, wisdom, knowledge, attitudes, or abilities which are necessary for managing an enterprise (Lackéus and Williams, 2015). Asange and Agwa (2018) outline entrepreneurial competence as "the skills and characteristics of entrepreneurs". By Ploum et al. (2017), the competencies are classified into strategic competencies, systems thinking competencies, relationship competencies, anticipation competencies, normative competencies, and diversity competencies. Entrepreneurs should be primarily innovative and creative and have the ability to change and risk-taking. Wickham (2006) states that entrepreneurs ought to be able to seek market opportunities. These additional needs require risk-taking, growth orientation, profit maximisation, and return on investment.

Entrepreneurial competence plays an essential role in many organisational elements and factors. Their relation to business performance is significant (Tehseen and Ramayah, 2015). Hoyos-Ruperto et al. (2013) report the impact on performance growth through the networking process. Entrepreneurial competence is also essential for SMEs to set up, organise, as they directly affect their performance (Sanchez, 2012) and their future survival. Sarwoko et al. (2013) state that entrepreneurial competence in SMEs mediates the relation between entrepreneurial characteristics and business performance.

Entrepreneurship has an essential role in society, especially in creating national policy and strategy (O'Brien and Hamburg, 2019). Developing entrepreneurship competencies and appropriate education are parts of Europe's national strategies (McCoshan et al., 2010). There are specifically targeted strategies (such as Great Britain, Belgium, Norway) and generally defined strategies related to entrepreneurship education (such as the Czech Republic, Spain, Cyprus). Key European policy documents have been drafted since 2003, when the first Entrepreneurship in Europe Green Paper (EC, EACEA and Eurydice, 2016) was written.

The results of a study administered among the entrepreneurs in New Zealand (Kirkwood, 2009) show that entrepreneurial motivation is predicated 
on the desire: to be independent, to earn cash, to eliminate issues in current employment, and the need to balance family and dealing life. People then feel free, independent of the environment. The latter factor is incredibly captivated by business and understanding of other relations such as family members. Paradoxically, the entrepreneurs may have less time for a family than employees. Their life could, therefore, be in a significantly larger imbalance than before beginning their business.

In previous research, the attention has focused primarily on men entrepreneurs; women are seen as less efficient in entrepreneurship (Marlow, 2014). Women tend to lack education or lack entrepreneurial experience, and they are expected to provide family care. Research reproduces the secondary role of women in entrepreneurship by making the masculine norm ideal (Brush et al., 2009). The authors describe three approaches to entrepreneurship according to gender. The environmental approach characterises motivation for beginning entrepreneurs (Lituchy and Reavley, 2004). Women entrepreneurs want to work that satisfies them likes new challenges and wants to be successful (Piperopoulos, 2012). The trait approach deals with the personality traits of entrepreneurs. There are similar traits for women and men: they are not afraid to take risks, they are creative and adaptable, they have good intuition, and they tend to be independent. The behavioural approach lists critical management skills for entrepreneurs. Women have problems raising capital, accounting and financial management (Lituchy and Reavley, 2004).

\section{MATERIALS AND METHODS}

The research included the participating university students in a questionnaire survey of 214 questionnaires in 2018-2019. The questionnaires classify students by gender into two categories: 60 men and 154 women. The research sample was determined by quota selection from the entire population of 1012 students who can attend the course of management at the University of South Bohemia in České Budějovice, mainly at the Faculty of Economics. We estimated the margin of error of $5.96 \%$ at the $95 \%$ confidence interval. The quota attribute was gender, which in the total student population is characterised by a ratio of $30.5 \%$ to $69.5 \%$ (men vs women). We verified the representativeness of the sample by the onesample chi-square test (Parke, 2013) at the level of significance alpha 0.05 . The result of chi-square is 0.629 and p-value 0.428 , which indicate that similar distribution of sample to the population (the null hypothesis of equality of the sample and population is not rejected). Based on the population's men and women ratio and the error rate found, we can consider the representative sample.
The participants assessed their attitude to business, business competence, and knowledge they would like to learn. The rating scored was from one (least useful) to seven (very useful). Tab. I describes all measured variables $\left(\mathrm{V}_{1}-\mathrm{V}_{19}\right)$ in the questionnaire.

I: Entrepreneurship education variables (EEV)

\begin{tabular}{ll}
$\mathrm{V}_{1}$ & $\begin{array}{l}\text { In my opinion, entrepreneurship is more } \\
\text { advantageous to me }\end{array}$ \\
$\mathrm{V}_{2}$ & $\begin{array}{l}\text { An entrepreneurship is, for me a tempting } \\
\text { professional life path }\end{array}$ \\
$\mathrm{V}_{3}$ & $\begin{array}{l}\text { The opportunity and the resources available would } \\
\text { convince me of becoming an entrepreneur }\end{array}$ \\
$\mathrm{V}_{4}$ & $\begin{array}{l}\text { Having my own business and become } \\
\text { entrepreneurship is my dream }\end{array}$ \\
$\mathrm{V}_{5}$ & $\begin{array}{l}\text { I would prefer being an entrepreneur between } \\
\text { the various career options }\end{array}$ \\
$\mathrm{V}_{6}$ & $\begin{array}{l}\text { My qualifications have contributed positively } \\
\text { to the idea of becoming an entrepreneur }\end{array}$ \\
$\mathrm{V}_{7}$ & Ability to assess market opportunities \\
$\mathrm{V}_{8}$ & $\begin{array}{l}\text { Ability to communicate, develop relations } \\
\text { and networking }\end{array}$ \\
$\mathrm{V}_{9}$ & Ability to cooperate with different stakeholders \\
$\mathrm{V}_{10}$ & Ability to make sacrifices to start a business \\
$\mathrm{V}_{11}$ & Creativity and ability to come up with changes \\
$\mathrm{V}_{12}$ & Ability to deal with problems and crises \\
$\mathrm{V}_{13}$ & External environment knowledge \\
$\mathrm{V}_{14}$ & Internal environment knowledge \\
$\mathrm{V}_{15}$ & Business characteristics \\
$\mathrm{V}_{16}$ & Business advantages and risks \\
$\mathrm{V}_{17}$ & Business concept and its structure \\
$\mathrm{V}_{18}$ & Necessary managerial competences \\
$\mathrm{V}_{19}$ & Developing the ability to recognise opportunity \\
\hline
\end{tabular}
Source: authors

\section{Exploratory Factor Analysis}

The Factor Analysis was chosen to divide the most important variables affecting student relations with entrepreneurship. Explorative factor analysis (Gorsuch, 2014) aims to analyse the correlation of a larger number of measurable variables and, accordingly, to identify groups of representative (latent) variables through a smaller number of common factors (latent variable). However, the number of factors found should be as low as possible. In the paper, the factor analysis helped determine the internal structure of the covariance of the index variables and the differentiation of the different groups of factors. Almost all correlation coefficients between variables are statistically significant at the level of 0.05 and meet Tabachnick and Fidell (2007). 
The suitability of our data for structure detection is analysed by the Kaiser-Meyer-Olkin (KMO) test. With the value $\mathrm{KMO}=0.8777$, the results of the index are very high. It means that the value is higher than 0.7 , and factor analysis can be performed very well (Cohen, 1988). In the next step, we use factor analysis to compare the group of men and women.

\section{Statistical Analysis}

The obtained results were analysed by statistical methods to compare two unrelated or independent samples (Corder and Foreman, 2009). For this purpose, the analysis is carried out separately for men and separately for women and the results then compared. Null working hypotheses, which form the subject matter of verification on the $5 \%$ level of significance, are the following:

$\mathrm{H}_{0}$ : There is no tendency for ranks of a group of male students to evaluate significantly different entrepreneurship education variables (EEV) than the group of female students.

$\mathrm{H}_{\mathrm{A}}$ : The alternative statistical hypothesis is that the ranks of the group of male students are systematically different from the group of female students.

ANOVA and Student t-test were used to evaluate differences in entrepreneurship education variables (EEV) according to gender. Only significant results are mentioned in the text, including the achieved level of significance (p-value). Statistica 12 software was used for the evaluation of working hypotheses.

\section{RESULTS}

Results are divided into two parts: factor analysis and hypotheses testing.

\section{Factor Analysis}

Factor extraction was performed using the Principal Component Analysis (PCA) method. Three factors found together explain $63.03 \%$ variance. The first factor is 6.9471, and the variance explained by this factor is $36.56 \%$. The second factor explains $13.59 \%$ of the variance and the third factor of $12.88 \%$ of the variance. The remaining factors are always less than $10 \%$ of the total variance, and their numbers are less than one. By Kaiser-Guttman criterion, it is appropriate to interpret only the first three factors as they explain more variance than the original variables. These results are also captured in Fig. 1.

When comparing results of the PCA method with other methods (for example multiple R2, MinRes, the Centroid method and Principal axis method), it was clear that the PCA achieves the highest degree of explained variance. For other methods, this was a maximum of $56 \%$. In all cases, the number of factors found amounted to three.

Factor loadings were calculated for each item in the extraction of factors, which represent correlations between factors and variables. So we can use them to interpret individual factors. As the initial factor extraction usually does not provide interpretable results, we performed a rotation using the Varimax method. Tab. II reveals the loadings greater than 0.7, expressing the important relation between manifested and latent variables. The results show that different variables relatively heavily saturate the factors.

The reliability of factor scores was analysed by Cronbach alfa. As revealed by Tab. II the coefficient is $0.7-0.9$ for all the factors. The last but one column in the table then indicates Cronbach's alpha values

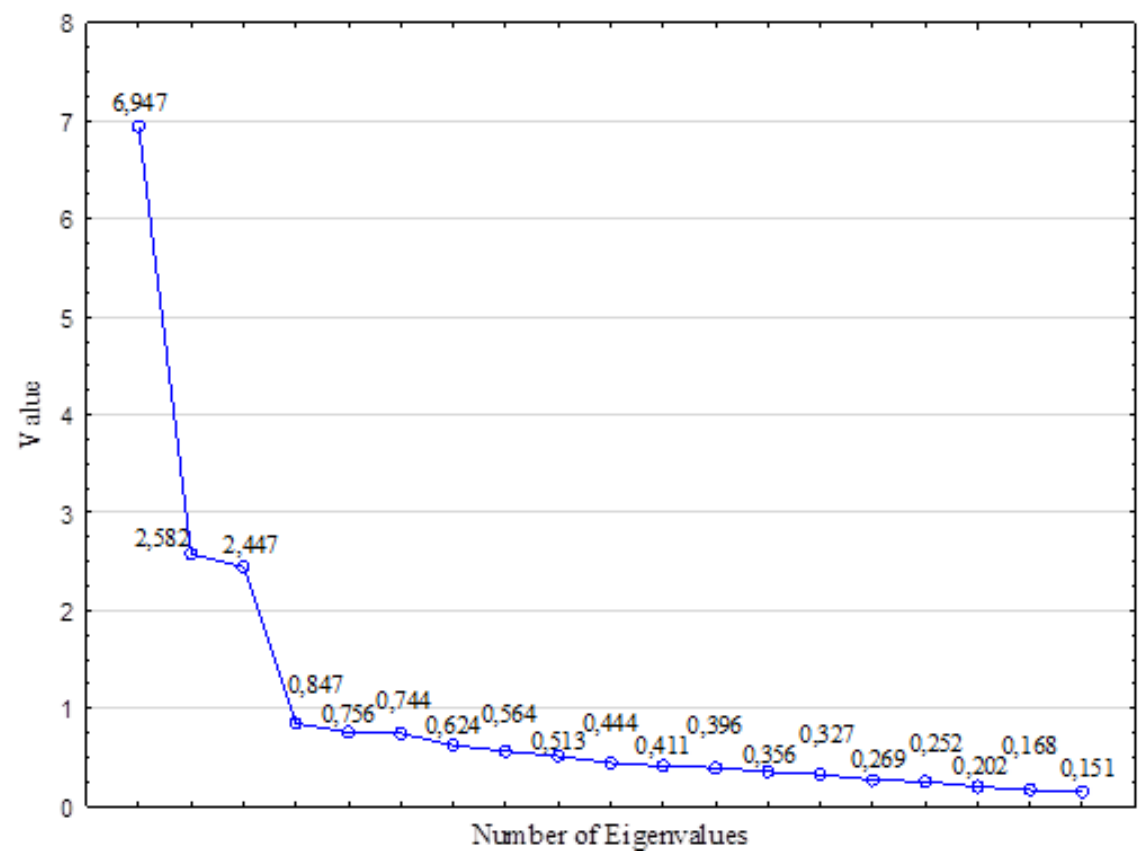

1: Screen Plot 
if the variable is deleted from the factor. In all cases, the reliability of the factors would be reduced.

Factor analysis results in three factors. Obviously, factor 1 is primarily saturated with $\mathrm{V}_{13}-\mathrm{V}_{19}$ variables. These variables have in common that they focus on the knowledge required by the students. The other factor, on the other hand, encompasses all the variables that make up the student's entrepreneurial competence. This means $\mathrm{V}_{7}-\mathrm{V}_{12}$. The last factor includes questions about students' attitudes towards entrepreneurship, which can be expressed through $\mathrm{V}_{1}-\mathrm{V}_{6}$ variables. Thus, the factors identified are:

Factor 1-knowledge that students would like to learn about business ( $\mathrm{V}_{13}-\mathrm{V}_{19}$ variables).

Factor 2 - business competence $\left(\mathrm{V}_{7}-\mathrm{V}_{12}\right.$ variables).

Factor 3 - a personal attitude of students to business $\left(\mathrm{V}_{1}-\mathrm{V}_{6}\right.$ variables).

\section{Students' Knowledge (Factor 1)}

Women mostly want to learn and acquire knowledge about assessing the internal environment of business (5.45). This knowledge help with analysis of the business plan. The second preferred knowledge is related to management competencies necessary for effective business management (5.34).
Men consider the most important knowledge in relation to learning how to recognise business opportunities (5.68), which is 0.4 points more compared to women. On average, the majority of male students report this competence as the most important (5.4). Correct recognition of the opportunity enables them to establish themselves better on the market and to strengthen their position and to increase the competitive advantage compared to other entrepreneurs.

The second place, as rated by men, is related to the acquired knowledge of the internal environment of enterprises (5.20). Interestingly, the less rated was the knowledge of the external environment of enterprises - it concerns competition, suppliercustomer relations, etc. (the average rating is lower than 4.8 as reported by Tab. III).

\section{Students' Competences (Factor 2)}

The most important competence of an entrepreneur, as rated by both male and female students, is the ability to deal with problems and crisis (the average rating by Tab. IV is approximately 5.3 points).

The second place is also attributed to the same competence, the ability to be creative and the art of change (on average about 5 points; for women, it is almost 0.2 points more than for men). The less

II: Rotated factor loadings (Varimax normalised)

\begin{tabular}{|c|c|c|c|c|c|}
\hline Variable number & Factor 1 & Factor 2 & Factor 3 & Alfa if deleted & Cronbach's alfa \\
\hline $\mathrm{V}_{1}$ & 0.1393 & 0.0492 & 0.7749 & 0.9183 & \multirow{6}{*}{$\begin{array}{l}\text { Cronbach's alpha } \\
\text { for factor } 3=0.9216\end{array}$} \\
\hline $\mathrm{V}_{2}$ & 0.2152 & 0.2387 & 0.8383 & 0.8975 & \\
\hline $\mathrm{V}_{3}$ & 0.2938 & 0.1797 & 0.7821 & 0.9065 & \\
\hline $\mathrm{V}_{4}$ & 0.1566 & 0.1380 & 0.8770 & 0.8974 & \\
\hline $\mathrm{V}_{5}$ & 0.1275 & 0.1769 & 0.8686 & 0.8986 & \\
\hline $\mathrm{V}_{6}$ & 0.1260 & 0.1136 & 0.7369 & 0.9224 & \\
\hline $\mathrm{V}_{7}$ & 0.0330 & 0.7675 & 0.2073 & 0.8378 & \multirow{6}{*}{$\begin{array}{l}\text { Cronbach's alpha } \\
\text { for factor } 2=0.8642\end{array}$} \\
\hline $\mathrm{V}_{8}$ & 0.0726 & 0.7340 & 0.2613 & 0.8409 & \\
\hline $\mathrm{V}_{9}$ & 0.1510 & 0.7638 & 0.2093 & 0.8329 & \\
\hline $\mathrm{V}_{10}$ & 0.1959 & 0.6450 & 0.1713 & 0.8570 & \\
\hline $\mathrm{V}_{11}$ & 0.1234 & 0.8051 & -0.0379 & 0.8391 & \\
\hline $\mathrm{V}_{12}$ & 0.1132 & 0.7847 & 0.0298 & 0.8397 & \\
\hline $\mathrm{V}_{13}$ & 0.7311 & 0.0334 & 0.1472 & 0.8503 & \multirow{7}{*}{$\begin{array}{c}\text { Cronbach's alpha } \\
\text { for factor } 1=0.8687\end{array}$} \\
\hline $\mathrm{V}_{14}$ & 0.6928 & 0.1922 & 0.1727 & 0.8510 & \\
\hline $\mathrm{V}_{15}$ & 0.6849 & 0.0406 & 0.1652 & 0.8578 & \\
\hline $\mathrm{V}_{16}$ & 0.7368 & 0.1368 & 0.0752 & 0.8505 & \\
\hline $\mathrm{V}_{17}$ & 0.7587 & 0.1329 & 0.1279 & 0.8448 & \\
\hline $\mathrm{V}_{18}$ & 0.7578 & 0.0803 & 0.0994 & 0.8482 & \\
\hline $\mathrm{V}_{19}$ & 0.7225 & 0.1473 & 0.2102 & 0.8478 & \\
\hline Total & 0.2107 & 0.1921 & 0.2275 & & \\
\hline
\end{tabular}

Source: authors 
rated by the students was the ability to evaluate a business opportunity (4.6). However, it is interesting that, by Tab. IV, this knowledge is the most important for women.

\section{Students' Personal Attitude (Factor 3)}

The results of personal attitudes include Tab. V. Most often, the students tend to opportunity, and resources are necessary for becoming an entrepreneur (average value 5.10). Men rate such opinion by 0.3 points more than women.

The statement that an entrepreneurial career is attractive scored second place among students. Even in this case, men rate such opinion by 0.35 points more. The least rated attitude among the students is that being an entrepreneur is a dream (average 3.7).
On average, men rated it by one point more compared to the women; they less dream of working as an entrepreneur. In the last place, men concluded that their qualifications would make a positive contribution to being an entrepreneur. It follows from this that they have not yet obtained the required qualifications (knowledge, competences) necessary for business.

\section{Statistical Analysis}

Tab. VI statistically compared the results adjusted, using the factors score by gender. For measuring differences, we used Cohen (1988) methodology of value $d$. The results show that for all factors, the difference in the test of variance was not significant. Furthermore, only factor 3 showed a statistically significant difference between gender groups.

III: Students' knowledge (mean of variables)

\begin{tabular}{clrrrr}
\hline No. & \multicolumn{1}{c}{ Variable } & Women & Men & Total \\
\hline $\mathrm{V}_{13}$ & External environment knowledge & 4.78 & 4.72 & 4.76 \\
\hline $\mathrm{V}_{14}$ & Internal environment knowledge & 5.45 & 5.20 & 5.38 \\
\hline $\mathrm{V}_{15}$ & Business characteristics & 4.97 & 5.05 & 5.00 \\
\hline $\mathrm{V}_{16}$ & Business advantages and risks & 5.23 & 5.02 & 5.17 \\
$\mathrm{~V}_{17}$ & Business concept and its structure & 5.00 & 5.02 & 5.00 \\
\hline $\mathrm{V}_{18}$ & Necessary managerial competences & 5.34 & 5.02 & 5.25 \\
$\mathrm{~V}_{19}$ & Developing the ability to recognise an opportunity & 5.28 & 5.68 & 5.39 \\
\hline
\end{tabular}

Source: authors

IV: Students' competences (mean of variables)

\begin{tabular}{clrrrr}
\hline No. & \multicolumn{1}{c}{ Variable } & Women & Men & Total \\
\hline $\mathrm{V}_{7}$ & Ability to assess market opportunities & 4.49 & 4.78 & 4.57 \\
$\mathrm{~V}_{8}$ & Ability to communicate and develop relations & 5.04 & 4.80 & 4.97 \\
$\mathrm{~V}_{9}$ & Ability to cooperate with different stakeholders & 4.90 & 4.88 & 4.89 \\
\hline $\mathrm{V}_{10}$ & Ability to make sacrifices to start a business & 4.52 & 4.87 & 4.62 \\
$\mathrm{~V}_{11}$ & Creativity and ability to come up with changes & 5.07 & 4.90 & 5.02 \\
$\mathrm{~V}_{12}$ & Ability to deal with problems and crises & 5.29 & 5.33 & 5.30 \\
\hline
\end{tabular}

Source: authors

V: Students' personal attitude (mean of variables)

\begin{tabular}{clccc}
\hline No. & \multicolumn{1}{c}{ Variable } & Women & Men & Total \\
\hline $\mathrm{V}_{1}$ & In my opinion, entrepreneurship is more advantageous to me & 4.34 & 4.82 & 4.48 \\
\hline $\mathrm{V}_{2}$ & An entrepreneurship is for me tempting professional life path & 4.65 & 5.00 & 4.75 \\
\hline $\mathrm{V}_{3}$ & $\begin{array}{l}\text { The opportunity and the resources available would convince me of } \\
\text { becoming an entrepreneur }\end{array}$ & 5.02 & 5.30 & 5.10 \\
\hline $\mathrm{V}_{4}$ & Having own business and become entrepreneurship is my dream & 3.46 & 4.40 & 3.72 \\
\hline $\mathrm{V}_{5}$ & I would prefer being an entrepreneur between the various career options & 3.96 & 4.63 & 4.15 \\
\hline $\mathrm{V}_{6}$ & $\begin{array}{l}\text { My qualifications have contributed positively to the idea of becoming an } \\
\text { entrepreneur }\end{array}$ & 3.58 & 4.22 & 3.76 \\
\hline
\end{tabular}

Source: authors 
VI: Gender differences (in \%)

\begin{tabular}{|c|c|c|c|c|c|c|c|c|}
\hline \multirow{2}{*}{ Factor } & \multicolumn{2}{|c|}{ Mean } & \multicolumn{2}{|c|}{ Test of variance } & \multicolumn{2}{|c|}{ t-test } & \multirow{2}{*}{$\begin{array}{c}\text { Effect size } \\
\text { d }\end{array}$} & \multirow{2}{*}{ Effect $^{1}$} \\
\hline & Women & Men & $\mathrm{F}$ & p-value & $\mathrm{t}$ & p-value & & \\
\hline Factor $1\left(\mathrm{~V}_{13}-\mathrm{V}_{19}\right)$ & 0.0385 & -0.0989 & 1.1805 & 0.4702 & 0.9024 & 0.3679 & 0.1374 & Small \\
\hline Factor $2\left(\mathrm{~V}_{7}-\mathrm{V}_{12}\right)$ & 0.0102 & -0.0262 & 1.0892 & 0.7199 & 0.2389 & 0.8114 & 0.0364 & Small \\
\hline Factor $3\left(\mathrm{~V}_{1}-\mathrm{V}_{6}\right)$ & -0.1254 & 0.3218 & 1.0987 & 0.6397 & -2.9923 & 0.0031 & 0.4471 & Medium \\
\hline
\end{tabular}

${ }^{1}$ small (>0.2), medium (>0.5), large (>0.8)

Source: authors

Consequently, the $\mathrm{H}_{0}$ hypothesis can be rejected as there are significant differences in personal attitudes to entrepreneurship among the students of a different gender at the significance level of 0.05 (p-value $=0.0031)$.

For other factors, the hypothesis cannot be rejected. However, the $V_{19}$ variable (form factor 1) was found to show significant differences between the genders ( $p$-value $=0.0471)$. It is the only variable of factor 1 .

\section{DISCUSSION}

The research identified the differences in management programme students related to entrepreneurship education based on gender. Our study uses the results of factor analysis, which is not widely used in management decision making for the needs of the future design of the entrepreneurship courses at the University. However, for example, Nieuwenhuien and Swanepoel (2015) study of business students in South Africa and Poland show the usefulness of factor analysis validation of an entrepreneurial intent instrument. Similarly, we used it to help narrow down the selection of questions in the questionnaire. By its application, 19 variables (questions) were divided into 3 factors: knowledge, competences and personal attitudes of students. The factor analysis confirmed the correct distribution of questionnaire questions.

The results show that the main difference is related to the approach to motivation to start a business, especially among the students of management programmes. Gender is an essential factor in this case. On average, most of all entrepreneurship education variables (EEV) are rated higher by men than women. Thus, entrepreneurship appears to be a more promising and attractive profession for men compared to women's perception. Schott, Kew and Cheraghi (2015) say that young women are often doubly disadvantaged in their attempts to integrate into the workforce - by their gender as well as by their age. Minniti and Naudé (2010) refer to the most critical factors of female entrepreneurship in their study. They see the following main factors of the differences: utility function of individuals, cultural factors and migrations, discrimination, knowledge of entrepreneurship activities and institutions. Similarly, Hughes et al. (2012) studied women's entrepreneurship within recent years and focused on general criticism, new directions and questions in research. Women often decide to start a business when they return to work after maternity leave, and their employer does not offer them a flexible working period. Entrepreneurship has the advantage for women that it allows them to work flexibly (Bohutínská, 2015).

The first factor relates to students' knowledge. The current knowledge in business and entrepreneurship is convinced that entrepreneurial qualities and abilities are not innate, but can be changed by education, training, and other life experiences (see Kuratko, 2013). After graduating course Entrepreneurship Support, students will have this knowledge: environment knowledge, business concept, advantages, risks, managerial competences. Studying women are very interested in the internal environment of the company (resource allocation, operations, human resources, financial or marketing analysis). They require managerial knowledge (performing managerial functions - e.g. planning, leadership, control, decision making, etc.). On the other hand, studying men want more to learn how to identify suitable business opportunities in the market. A comprehensive study of entrepreneurial education in Visegrad countries shows that there are several differences across the four nations.

Furthermore, a gender comparison indicates lower entrepreneurial intentions of women, which should be foster and support by entrepreneurship education (Nowinski et al., 2019). According to the results, the students want to learn most about the internal environment of business, while the least they want to learn about the external environment. The main reason is that the analysis of the external environment is discussed in more detail in the subject of management. Therefore, the students are already educated in this field. There was no significant gender difference in the required knowledge. The most critical knowledge for the business is how to build a business plan and its structure. We found in the lower half of the required types of knowledge. Obtained information about preferred knowledge will allow better allocation of time-related to the topics of the preparation course. More time in lectures and exercises will be given to the preferred knowledge as reported by the students. 
The second factor concerns the necessary competencies for entrepreneurship. The main aim of entrepreneurial education is to grow and foster entrepreneurial competences. According to students, entrepreneurs must solve problems and manage change (be able to make the right decisions, have the necessary information, come up with innovative solutions and overcome the resistance of employees to change). Less essential for them to is the recognition of opportunities, which is the knowledge they learn at university. In practice, they already do business in their area, and their effort is to develop their business. However, they must not forget to innovate their products and always be ahead of the competition. Ahmad et al. (2010) research deal with dimensions of entrepreneurial competences. Their research confirmed that the crucial competencies include: the ability to communicate, cooperate, assess opportunities, creativity and deal with the problem. Similarly, Munoz-Fernandez, Rodrigues-Gutierrez and Santos-Roldan (2016) published a study of interpersonal skills and competencies which determine the entrepreneurial profile among students in Spain. Women entrepreneurs have a higher score in psychological and behaviour-related competencies (Garcia and Capitan, 2018). Also, the results, as reported by this paper, confirms that the most important competence is to be able to work with changes and deal with possible crises. According to the students, the least needed is the ability to recognise opportunities. Again, no gender differences were confirmed. This finding will also give equal attention to ensuring that the students (both women and men) acquire the same and necessary entrepreneurial competencies they prefer.

The third factor characterises students' attitudes toward entrepreneurship. Results show that both groups of students - studying men and women - have not the same attitude to becoming an entrepreneur. Entrepreneurship attitudes are different according to gender, and this is an exciting result. Women usually have less motivation to start a new business due to risk aversion. Women realise that necessary financial capital and business information are essential. The business plan should help students answer questions about the viability of their entrepreneurship. There are many ways to get the necessary finance for business (most often a bank loan). That is why the AMSP ČR and Ženy s.r.o. (2014) annually announces the Grant Program Enterprise woman of the year when the ten most exciting business stories receive an attractive financial reward. Women need to be supported in their intention to enter the business and in their general awareness of their abilities, which are sufficient for starting their own business. The interest in the study of entrepreneurial courses was on average higher for men (Wehrwein, Lujan and DiCarlo, 2007). The gender gap between women and men started since childhood. Specific education policies and strategies for female students are also valuable to promote entrepreneurship competences.

According to Nel, Maritz and Thongpravati (2010), the core of a person's intrinsic business motivation is the need for success and independence. DeTienne and Chandler (2018) presented a study of entrepreneurship gender differences. The main problems have women with identification of opportunities. Dilli and Westerhuis (2018) explain how entrepreneurial activity is influenced by gender. Their research shows that equality of access to scientific education affects skills and competences for entrepreneurship, particularly in knowledgebased sectors. Therefore, in order to avoid discrimination against women, these differences in the education system should be eliminated. Their entrepreneurial motivation and entrepreneurship would then increase.

On the other hand, the annual analysis in the Czech Republic that it is already becoming a trend whereby women are starting up more business than men (Cfoworld, 2017). The most common impulse for this decision is that women do not enjoy it in their work; they want to achieve independence. Women also trust themselves more than in the past (AMSP ČR and Ženy s.r.o., 2014). It is undoubtedly related to the aspect and current trend of equal gender opportunities. It may be related to the growing availability of the Internet, thanks to which many women are launching e-shops on maternity leave. In our research, female students do not dream so much of starting a business as men. Lukeš and Jakl (2007) also state that starting your own business is not very attractive for women in the Czech Republic. It will, therefore be necessary to persuade female students about the benefits of doing business.

\section{CONCLUSION}

In conclusion, we have examined differences among the students of management programmes in entrepreneurship education. Based on a questionnaire survey among university students of management fields, we tested a total of nineteen variables relating to entrepreneurship. We have shown that the main variables of students' entrepreneurship are competences, knowledge and personal attitudes. The difference between the genders was statistically demonstrated only by factor 3 regarding the attitude of students to entrepreneurship. Factor 2 (entrepreneurship competence) and Factor 1 (entrepreneurship knowledge) did not show any difference in responses between women and men. This research has made a substantial contribution to the management decision-making on the future form of the business course. It is, therefore, possible to offer all students the same topics of 
entrepreneurship within the upcoming course Entrepreneurship Support and thanks to practical exercises and writing a business plan; students will also have the same entrepreneurial competences. The study deals with a fundamental gender issue, and its results can be beneficial for the areas of management and education, especially for their overlap.

The benefits of this work were disseminated to the relevant research communities and universities. University is one of the virtual environments for developing entrepreneurial competencies so that educators are considered crucial actors in entrepreneurship education. A management program that offers courses in Entrepreneurship shall provide possibilities of maximising the potential of entrepreneurial education, hence students will grow more inclined with the thought of being an entrepreneur in the future while possessing excellent leadership skills. Entrepreneurship-based courses should be incorporated into the curriculum of all faculties and should not be limited to the Faculty of Economics. Non-business students should have opportunities to compete for start-up funding through endowed entrepreneurship programs.

Furthermore, it is also necessary to initiate an interest of students in entrepreneurial courses, using appropriate marketing strategies. More people motivated to be an entrepreneur and start their businesses help the national economy. The authors will continue to research regarding the students and their attitudes towards entrepreneurship so that it will be possible to best tailor the content of the Entrepreneurship Support course. Future research will focus on the investigation of variables related to successful entrepreneurs. We will find out their motivation, competence and attitudes towards entrepreneurship concerning gender differences. We will compare their results with students.

Acknowledgements

This paper was supported by OPVVV Rozvoj JU - ESF:CZ.02.2.69/0.0/0.0/16_015/0002348.

\section{REFERENCES}

AHL, H. and MARLOW, S. 2012. Exploring the dynamics of gender, feminism and entrepreneurship: advancing debate to escape a dead end? Organisation, 19(5): 543-562.

AHMAD, N. H., RAMAYAH, T., WILSON, C. and KUMMEROW, L. 2010. Is Entrepreneurial Competency and Business Success Relationship Contingent Upon Business Environment? International Journal of Entrepreneurial Behaviour \& Research, 16(3): 182-203.

AMSP ČR and ŽENY, S.R.O. 2014. Women's attitudes to entrepreneurship [in Czech: Postoje žen k podnikáni]. AMSP ČR and Ženy, s.r.o. [Online]. Available at: https://amsp.cz/uploads/Pruzkumy/ Pruzkum_podnikani_zen.pdf [Accessed: 2020, December 20].

ASENGE, E. L. and AGWA, T. R. 2018. Entrepreneurial Competencies and Entrepreneurial Mindset as Determinants of Small and Medium Scale Enterprises Performance in Nigeria. Global Journal of Management and Business Research: A Administration and Management, 18(13): 1-11.

BOHUTÍNSKÁ, J. 2015. What pushes businesswomen to success [in Czech: Co tlačí podnikatelky k úspěchu]. Podnikatel.cz. [Online]. Available at: https://www.podnikatel.cz/clanky/co-tlacipodnikatelky-k-uspechu-vytrvalost-a-touha-po-samostatnosti/ [Accessed: 2019, December 18].

BRUSH, C. G., DE BRUIN, A. and WELTER, F. 2009. A gender-aware framework for women's entrepreneurship. International Journal of Gender and Entrepreneurship, 1(1): 8-24.

BURCH, T., MURPHY, G. and TOCHER, N. 2019. Entrepreneurship Education enrollment intentions: The effect of attitudes, norms and personality. Journal of Developmental Entrepreneurship, 24(3): 1-20.

CFOWORLD. 2017. Women are more interested in entrepreneurship than men [in Czech: Ženy jeví o živnostenské podnikání vyšší zájem než muži]. CFOworld. [Online]. Available at: https://cfoworld. cz/analyzy/zeny-jevi-o-zivnostenske-podnikani-vyssi-zajem-nez-muzi-4295 [Accessed: 2019, June 16].

COHEN, J. W. 1988. Statistical power analysis for the behavioral sciences. Hillsdale, NJ: Lawrence Erlbaum Associates.

CORDER, G. W. and FOREMAN, D. I. 2009. Nomparametric Statistics for Non-Statisticians: A step-by-step approach. New Jersey: John Wiley \& Sons.

DETIENNE, D. R. and CHANDLER, G. N. 2007. The role of gender in opportunity identification. Entrepreneurship Theory and Practice, 31(3): 365-386.

DILLI, S. and WESTERHUIS, G. 2018. How institutions and gender differences in education shape entrepreneurial activity: a cross-national perspective. Small Business Economics, 51(2): 371-392.

DLOUHÁ, M., JURIK, N. C., and KŘÍŽKOVÁ, A. 2014. Gender innovation in small business. Gender, Rovné Př́ležitosti, Výzkum, 15(2): 87-100. 
EC, EACEA and EURYDICE. 2016. Entrepreneurship Education at School in Europe. Eurydice Report. Brussels: Education, Audiovisual and Culture Executive Agency. Available at: https://eacea. ec.europa.eu/national-policies/eurydice/content/entrepreneurship-education-school-europe_en [Accessed: 2019, October 15].

FELLNHOFER, K. 2019. Toward a taxonomy of entrepreneurship education research literature: A bibliometric mapping and visualization. Educational Research Review, 27: 28-55.

GARCIA, P. O. and CAPITAN, A. O. 2018. Competence factors in the entrepreneurship of women. Revista Espanola De Sociologia, 27(3): 413-432.

GORSUCH, L. R. 2014. Factor Analysis. New York: Routledge.

GÜROL, Y. and ATSAN, N. 2005. Entrepreneurial Characteristics amongst University Students: Some Insights for Entrepreneurship Education and Training in Turkey. Education and Training, 48(1): 25-38.

HOYOS-RUPERTO, D. M. et al. 2013. Networking: A Critical Success Factor for Entrepreneurship. American Journal of Management, 13(2): 55-72.

HUGHES, K. D., JENNINGS, J., BRUSH, C., CARTER, S. and WELTER, F. 2012. Extending women's entrepreneurship research in new directions. Entrepreneurship Theory and Practice, 36(3): 429-442.

INYANG, B. J. and ENUOH, R. O. 2009. Entrepreneurial Competencies: The Missing Links to Successful Entrepreneurship in Nigeria. International Business Research, 2(2): 62-71.

JURIK, N. C., KŘÍŽKOVÁ, A. and POSPÍŠILOVÁ, M. 2016. Czech copreneur orientations to business and family responsibilities: a mixed embeddedness perspective. International Journal of Gender and Entrepreneurship, 8(3): 307-326.

KIRKWOOD, J. 2009. Motivational factors in a push-pull theory of entrepreneurship. Gen-der in Management: An International Journal, 24(5): 346-364.

KŘİŽKOVÁ, A., MAŘÍKOVÁ, H., HAŠKOVÁ, H. and FORMÁNKOVÁ, L. 2011. Women's careers in the Czech Republic [in Czech: Pracovní dráhy žen v České republice]. Praha: SLON.

KURATKO, D. F. 2013. Entrepreneurship education: Emerging trends and challenges for the $21^{\text {st }}$ century. Coleman Foundation White Paper Series for the U. S. Association of Small Business \& Entrepreneurship.

KUTTIM, M., KALLASTE, M., VENESAAR, U. and KIIS, A. 2014. Entrepreneurship Education at University Level and Students' Entrepreneurial Intentions. Social and Behavioral Sciences, 110: 658-668.

LACKÉUS, M. and WILLIAMS, M. K. 2015. Venture Creation Programs - Bridging Entrepreneurship Education and Technology Transfer. Education + Training, 57(1): 48-73.

LITUCHY, T. R. and REAVLEY, M. A. 2004. Women entrepreneurs: A Comparsion of International Small Business Owners in Poland and the Czech Republic. Journal of International Entrepreneurship, 2(1-2): 61-87.

LUKEŠ, M. and JAKL, M. 2007. Business activity in the Czech Republic [in Czech: Podnikatelská aktivita v České republice]. [Online]. Global Entrepreneurship Monitor. Available at: http://www. gemconsortium.org/document.aspx?id=582 [Accessed: 2020, December 20].

MARLOW, S. 2014. Exploring future research agendas in the field of gender and entrepreneurship. International Journal of Gender and Entrepreneurship, 6(2): 102-120.

MATLAY, H. and WESTHEAD, P. 2005. Virtual teams and the rise of e-entrepreneurship in Europe. International Small Business Journal, 12(3): 353-365.

MCCOSHAN, A., LOYD, P., BLAKEMORE, M., GLUCK, D., BETTS, J., LEPROPRE, M. and MCDONALD, N. (Eds.). 2010. Towards Greater Cooperation and Coherence in Entrepreneurship Education, Report and evaluation of the pilot action High Level Reflection Panels on Entrepreneurship Education initiated by DG Enterprise and Industry and DG Education and Culture. Birmingham: ECOTEC.

MCGEE, J. E., PETERSON, M., MUELLER, S. L. and SEQUEIRA, J. M. 2009. Entrepreneurial self-efficacy: refining the measure. Entrepreneurship theory and practice, 33(4): 965-988.

METRO. 2020. International study on private enterprise [in Czech: Mezinárodní studie o soukromém podnikání]. METRO. Available at: https://amsp.cz/wp-content/uploads/2019/10/MAKRO_ Mezinarodni_studie_o_soukromem_podnikani.pdf.

MINNITI, M. and NAUDÉ, W. 2010. What do we know about the patterns and determinants of female entrepreneurship across countries? The European Journal of Development Research, 22(3): 277-293.

MUNOZ-FERNANDEZ, G. A., RODRIGUEZ-GUTIERREZ, P. and SANTOS-ROLDAN, L. 2016. Entrepreneurship in Higher Education in Tourism, gender issue? Electronic Journal of Research in Educational Psychology, 14(1): 45-65.

NEL, P., MARITZ, A. and THONGPROVATI, O. 2010. Motherhood and entrepreneurship: The mumpreneur phenomenon. International Journal of Organizational Organisational innovation, 3(1): 6-34.

NIEUWENHUIZEN, C. and SWANEPOEL, E. 2015. Comparison of the entrepreneurial intent of master's business students in developing countries: South Africa and Poland. Acta Commercii, 15(1): 1-10. 
NOWINSKI, W., HADDOUD, M. Y., LANCARIC, D., EGEROVA, D. and CZEGLEDI, C. 2019. The impact of entrepreneurship education, entrepreneurial self-efficacy and gender on entrepreneurial intentions of university students in the Visegrad countries. Studies in Higher Education, 44(2): 361-379.

O'BRIEN, E. and HAMBURG, I. 2019. A critical review of learning approaches for entrepreneurship education in a contemporary society. European Journal of Education, 54(4): 525-537.

PARKE, S. C. 2013. Essential First Steps to Data Analysis: Scenario-Based Examples Using SPSS. London: Sage.

PIHIE, Z. A. L. and AKMALIAH, Z. 2009. Entrepreneurship as a career choice: An analysis of entrepreneurial self-efficacy and intention of university students. European Journal of Social Sciences, 9(2): 338-349.

PIPEROPOULOS, P. G. 2012. Entrepreneurship, Innovation \& Business Clusters. Farnham: Gower Publishing.

PLOUM, L., BLOK, V., LANS, T. and OMTA, O. 2018. Toward a Validated Competence Framework for Sustainable Entrepreneurship. Organization \& Environment, 31(2): 113-132.

PULKA, B. M., RIKWENTISHE, R. and IBRHAIN, B. 2014. Evaluation of Students' Attitude to-wards entrepreneurship education in some selected universities in North East Nigeria. Global Journal of Management and Business Research, 14(8): 1-8.

RUDHUMBU, N., SVOTWA, D., MUNYANYLWA, T. and MUTSAU, M. 2016. Attitudes of Students towards Entrepreneurship Education at Two Selected Higher Education Institutions in Botswana: A Critical Analysis and Reflection. Academic Journal of Interdisciplinary Studies, 5(2): 83-94.

SANCHEZ, J. 2012. The Influence of Entrepreneurial Competencies on Small Firm Performance. Revista Latinoamericana de Psicologia, 44(2): 165-177.

SARWOKO, E. et al. 2013. Entrepreneurial Characteristics and Competency as determinants of Business Performance in SMEs. Journal of Business and Management, 7(3): 31-38.

SCHOTT, T., KEW, P. and CHERAGHI, M. 2015. Future Potential: A GEM Perspective on Youth Entrepreneurship. Odense: University of Southern Denmark. Available at: http://www.innovacion.cl/ wp-content/uploads/2015/08/gem-2015-youth-report-1436523546.pdf [Accessed: 2019, October 20].

STOICA, O., ROMAN, A. and RUSU, V. D. 2020. The Nexus between Entrepreneurship and Economic Growth: A Comparative Analysis on Groups of Countries. Sustainability, 12(3): 1186.

TABACHNICK, B. G. and FIDELL, L. S. 2007. Using Multivariate Statistics. New York: Allyn and Bacon.

TEHSEEN, S. and RAMAYAH, T. 2015. Entrepreneurial Characteristics and SMEs Business Success: The Contingent Role of External Integration. Mediterranean Journal of Social Sciences, 6(1): 50-61.

WEHRWEIN, E. A., LUJAN, H. L. and DICARLO, S. E. 2007. Gender differences in learning style preferences among undergraduate physiology students. Advances in Physiology Education, 31(2): 153-157.

WEI, X. J., LIU, X. L. and SHA, J. 2019. How Does the Entrepreneurship Education Influence the Students' Innovation? Testing on the Multiple Mediation Model. Frontiers in Psychology, 10: 1557.

WICKHAM, P. 2006. Strategic Entrepreneurship. London: Financial Times Prentice-Hall.

Contact information

Martin Pech: mpechac@ef.jcu.cz (corresponding author)

Petr Řehoř: rehor@ef.jcu.cz 
